\title{
PEMETAAN STRUKTUR BIDANG ILMU MENGGUNAKAN ANALISIS JEJARING SOSIAL: PERUBAHAN BIDANG ILMU PUBLIKASI PENELITIAN KELAUTAN DAN PERIKANAN INDONESIA
}

\author{
Rizka Rahmaida \\ Pusat Penelitian Perkembangan Iptek - Lembaga Ilmu Pengetahuan Indonesia \\ Korespondensi: rizkarahmaida@gmail.com
}

Diajukan: 15 November 2016; Direview: 16 November 2016; Diterima: 24 Maret 2017; Direvisi: 30 Maret 2017

\begin{abstract}
Indonesia is a maritime country with two-third of its total area consist of water. Research on marine and fisheries studies should be considered as an important matter in Indonesia. Studies on research development can be a way to evaluate and to determine research policy direction. The increasing of scientific publication database draws the need for enhancement to their quantitative techniques analysis to understand research structure; social and science structure. This study aims to map the subject area, that covered research on marine and fisheries studies and carried out by institution located in Indonesia. Social network analysis is used to show the relationship of subject area in the related research. Data that is used in this research is based on marine and fisheries studies that conducted in Indonesia and indexed by Scopus for the last ten years (2006-2015). The network map shows that the publication has changed in terms of the covered subject areas and the relationship among them. The result of this study can be used to evaluate and to support marine and fisheries research policy direction in Indonesia.
\end{abstract}

\begin{abstract}
ABSTRAK
Indonesia merupakan negara maritim dengan luas lautan dua pertiga luas total wilayahnya. Penelitian kelautan dan perikanan sudah selayaknya menjadi hal yang penting di negara ini. Kajian mengenai perkembangan penelitian dapat menjadi bahan untuk mengevaluasi dan menentukan arah kebijakan penelitian. Perkembangan basis data publikasi ilmiah menyebabkan peningkatan kebutuhan analisis kuantitatif untuk memahami struktur dari suatu penelitian baik struktur sosial maupun struktur ilmu di dalamnya. Penelitian ini bertujuan untuk memetakan cakupan bidang ilmu penelitian kelautan perikanan yang dilakukan oleh institusi di Indonesia. Analisis jejaring sosial digunakan untuk memperlihatkan hubungan keterkaitan antar bidang ilmu di dalam penelitian kelautan dan perikanan. Data yang digunakan dalam penelitian ini adalah publikasi ilmiah kelautan dan perikanan Indonesia yang terindeks Scopus selama sepuluh tahun terakhir (2006-2015). Peta jejaring bidang ilmu selama sepuluh tahun terakhir menunjukkan bahwa publikasi ilmiah kelautan dan perikanan mengalami perubahan dalam bidang ilmu yang tercakup, dan keterkaitan antar bidang ilmu di dalamnya. Hasil penelitian ini dapat digunakan untuk mengevaluasi dan memberikan masukan kebijakan arah penelitian kelautan dan perikanan di Indonesia.
\end{abstract}

Keywords: Science; Social network; Data analysis; Data management; Fisheries; Marine survey; Indonesia

\section{PENDAHULUAN}

Indonesia merupakan negara kepulauan terbesar di dunia yang memiliki potensi besar untuk menjadi poros maritim dunia. Dalam sambutannya di Konferensi Tingkat Tinggi (KTT) Asia Timur, Presiden Jokowi menegaskan bahwa beliau bertekad untuk menjadikan Indonesia menjadi poros maritim dunia. Poros maritim merupakan sebuah gagasan strategis yang diwujudkan untuk menjamin konektivitas antar pulau, pengembangan industri perkapalan dan perikanan, perbaikan transportasi laut serta fokus pada keamanan maritim (Kementerian Sekretariat Negara RI, 2015). Alfred Thayer Mahan dalam bukunya yang berjudul "The 
Influence of Sea Power upon History", mengemukakan teori bahwa kekuatan laut merupakan unsur terpenting bagi kemajuan dan kejayaan suatu negara. Jika kekuatan-kekuatan laut tersebut diberdayakan, maka akan meningkatkan kesejahteraan dan keamanan suatu negara. Sebaliknya, jika kekuatan-kekuatan laut tersebut diabaikan akan berakibat kerugian bagi suatu negara atau bahkan meruntuhkan negara tersebut (Hardiana \& Trixie, 2014). Secara geografis Indonesia merupakan negara kepulauan terbesar. Sebanyak tiga perempat wilayahnya atau sekitar 5,9 juta $\mathrm{km}^{2}$ merupakan lautan (Lasabuda, 2013). Indonesia juga menempati urutan kedua setelah Kanada sebagai negara yang memiliki garis pantai terpanjang di dunia, yaitu sepanjang $95.161 \mathrm{~km}$. Kekuatan inilah yang merupakan potensi besar untuk memajukan perekonomian Indonesia.

Berdasarkan data Food and Agriculture Organization tahun 2013, pada saat ini Indonesia menempati peringkat kedua terbesar dunia dalam produksi perikanan tangkap di bawah China. Sedangkan dalam hal produksi perikanan budidaya, Indonesia menempati urutan ketiga setelah China dan India (FAO, 2015). Dilihat dari potensi minyak bumi, perairan Indonesia menyimpan 70 persen potensi minyak. Besarnya potensi ini dikarenakan terdapat kurang lebih 40 cekungan minyak yang berada di perairan Indonesia. Dari angka tersebut hanya sekitar 10 persen yang saat ini telah dieksplorasi dan dimanfaatkan (Hardiana \& Trixie, 2014). Dengan dmikian, masyarakat Indonesia belum merasakan potensi kelautan dan perikanan yang dimiliki. Hal ini ditandai dengan pengelolaan potensi maritim Indonesia yang belum dikelola secara maksimal. Potensi maritim Indonesia yang beragam sebenarnya dapat memberikan kontribusi bagi kesejahteraan dan kemakmuran rakyat Indonesia. Beberapa potensi lainnya, antara lain industri bioteknologi kelautan, perairan, wisata bahari, energi kelautan, mineral laut, pelayaran, pertahanan, dan industri maritim.

Iptek merupakan sektor penting bagi suatu bangsa, sama pentingnya dengan sektor ekonomi, pertanian, dan industri. Dengan penguasaan iptek, suatu negara dapat meningkatkan taraf hidup bangsanya dengan menjalankan ekonomi berbasis pengetahuan, bukan lagi ekonomi berbasis sumber daya. Potensi sumber daya kelautan yang besar dapat dimanfaatkan untuk masyarakat salah satunya melalui kegiatan penelitian. Informasi mengenai perkembangan ilmu pengetahuan diperlukan untuk menentukan arah kebijakan terkait ilmu pengetahuan dan teknologi. Salah satu cara untuk melihat perkembangan ilmu pengetahuan adalah dengan melihat perkembangan publikasi ilmiah. Adanya gambaran pola publikasi ilmiah kelautan dan perikanan dapat membantu mengoptimalkan penelitian ke depan yang dilakukan. Analisis mengenai publikasi ilmiah merupakan salah satu bagian dari saintometrika. Saintometrika merupakan kajian kuantitatif dalam kajian kebijakan iptek. Data yang digunakan tidak terbatas pada data publikasi ilmiah saja, tetapi juga data terkait iptek dari aspek ekonomi, anggaran, sosial, budaya.

Bibliometrika merupakan bagian dari saintometrika yang menggunakan data publikasi ilmiah dalam analisisnya. Data publikasi memberikan informasi mengenai aktivitas ilmiah dalam tiga aspek (Spasser, 1997). Ketiga aspek tersebut, yaitu hasil aktivitas ilmiah (produk), transfer pengetahuan (proses), serta jejaring intelektual dan sosiokognitif (struktur). Spasser (1997) menyebutkan seiring adanya peningkatan tingkat kerumitan sistem aktivitas ilmiah terdapat kebutuhan pengunaan teknik kuantitatif untuk memahami aspek struktur dan dinamikanya. Terdapat beberapa kajian bibliometrika yang membahas penelitian kelautan dan kemaritiman. Bruno (2006) melakukan penelitian saintometrika untuk menghasilkan gambaran tema penelitian yang berperan dalam manajemen sumber daya kelautan menggunakan analisis co-word. Kumaresan, et al (2015) melakukan penelitian untuk menganalisis produktivitas 
publikasi. Dias, et al (2012) melakukan penelitian saintometrika untuk menganalisis publikasi ilmiah untuk mengetahui apakah penelitian terkait keramba jaring telah mempertimbangkan isu lingkungan atau hanya membahas isu peningkatan produksi. Hasil penelitian tersebut menunjukkan bahwa penelitian terkait keramba jaring masih banyak membahas produksi perikanan. Penelitian rumput laut selama tahun 2005-2014 terkait produktivitas per tahun, jenis publikasi, jurnal, institusi, dan negara yang paling produktif.

Di Indonesia, kajian saintometrika terkait penelitian kemaritiman belum banyak dilakukan. Sebagian besar kajian saintometrika yang dilakukan di Indonesia merupakan kajian bibliometrika. Terdapat beberapa penelitian bibliometrika di Indonesia. Nadhiroh (2015) melakukan penelitian saintometrika untuk menganalisis jejaring co-authorship menggunakan metode analisis jaringan sosial biner pada penelitian kelautan. Penelitian ini menggunakan kata pencarian "marine" pada basis data Web of Science. Maryati, dkk (2016) mengatakan bahwa penelitian terkait sumber daya kelautan belum bersifat multidisiplin. Penelitian ini menggunakan tiga sumber basis data dan beberapa kata kunci. Kata kunci "kearifan lokal", "sumber daya laut" digunakan untuk pencarian dalam Indonesian Scientific Journal Database (ISJD). Kata kunci "marine", "income" ,Indonesia", "local wisdom", "marine resources" digunakan untuk pencarian dalam Aquatic Sciences and Fisheries Abstracts (ASFA) Proquest. Sedangkan pencarian dalam basis data Scopus digunakan kata kunci "marine" and "resource" serta "marine" and "income".

Berdasarkan latar belakang di atas terlihat bahwa belum ada penelitian yang membahas struktur bidang ilmu penelitian kelautan dan perikanan Indonesia sehingga penulis tertarik untuk melakukan penelitian mengenai hal tersebut. Penelitian ini bertujuan untuk memetakan bidang ilmu dalam penelitian perikanan dan kelautan periode 2006-2010 dan 2011-2015 dan mengidentifikasi perubahan yang terjadi pada kedua periode tersebut.

\section{TINJAUAN PUSTAKA}

Jejaring sosial merupakan salah satu cara untuk menggambarkan hubungan. Pola hubungan antar individu dapat digambarkan melalui jejaring sosial (Newman, Barabasi, \& Watts, 2006). Jejaring sosial juga dapat menggambarkan pola hubungan antar organisasi. Beberapa pola hubungan antar individu seperti, persahabatan, co-authorship (Monclar, 2011), kolaborasi dan hubungan bisnis (Newman, 2004) juga dapat digambarkan dalam jejaring sosial. Individu atau organisasi yang saling berhubungan untuk tujuan tertentu merupakan hal penting yang harus ada dalam struktur sosial yang digambarkan dalam jejaring sosial.

Analisis mengenai jejaring sosial pada dasarnya merupakan perluasan teori graf. Matriks matematika seringkali digunakan untuk menggambarkan hubungan antar aktor dalam jejaring tersebut (Katerndahl, 2012). Dengan demikian, konsep jejaring sosial dapat lebih mudah dipahami. Streeter dan Gillespie (1992) menyatakan bahwa matriks telah menjadi pendekatan yang banyak digunakan dalam analisis jejaring beberapa tahun terakhir. Keseluruhan informasi dalam grafik dapat digambarkan melalui matriks. Dalam jejaring yang memiliki bobot, matriks akan mempermudah analisis kuantitatif yang dilakukan karena nilainilai yang tersusun dalam baris dan kolom matriks merupakan interpretasi hubungan antara dua anggota dalam jejaring tersebut.

Wasserman dan Faust (1994) menyatakan bahwa hubungan dalam suatu jejaring dapat berupa hubungan tidak berarah atau hubungan berarah. Dalam hubungan tidak berarah, hubungan yang terjadi bersifat simetris, misalnya jika diketahui A bertetangga dengan $\mathrm{B}$, maka B juga bertetangga dengan A. Sementara itu, dalam suatu hubungan berarah, seseorang 
merupakan sumber yang mengawali adanya hubungan sedangkan orang lain merupakan penerima atau tujuan hubungan. Salah satu contoh dalam suatu hubungan berarah yaitu, ketika terjadi surat-menyurat antara dua orang. Jika diketahui A mengirim surat kepada B, maka tidak berarti B mengirim surat kepada A. Dalam suatu hubungan tak berarah, tidak ada sumber maupun tujuan yang menjadi asal maupun tujuan hubungan. Ilustrasi jejaring yang memiliki hubungan berarah dan tidak berarah dapat dilihat pada Gambar 1.
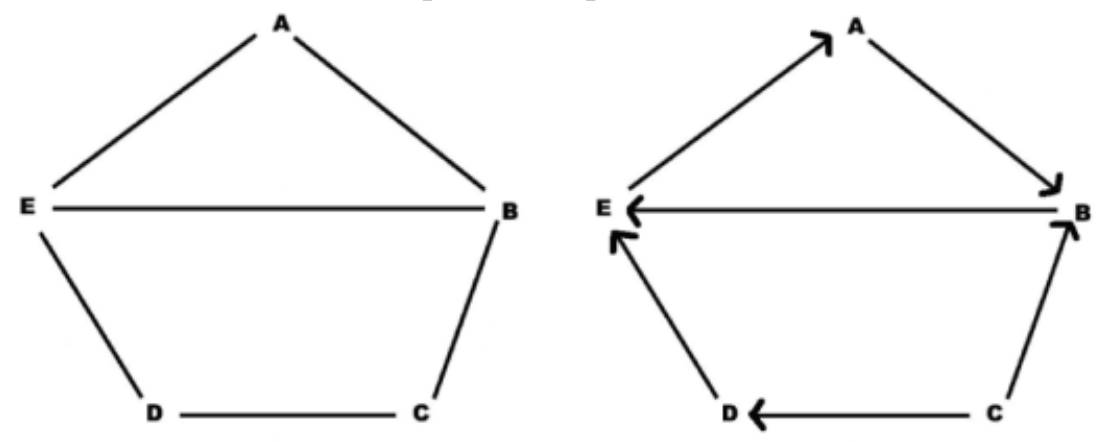

Gambar 1. Hubungan tak berarah (a) dan hubungan berarah (b)

Seperti yang telah disebutkan sebelumnya, jejaring yang di dalamnya terdapat hubungan tak berarah dan hubungan berarah dapat digambarkan dalam matriks. Jejaring tak berarah di dalamnya terdiri dari hubungan tak berarah. Dalam notasi matriks, jejaring tak berarah A dapat digambarkan sebagai matriks A. Matriks untuk jejaring tak berarah A hanya terdiri dari angka 0 dan 1 , di mana $a_{i j}=0$ berarti tidak ada hubungan antara $\mathrm{i}$ dan $\mathrm{j}$, dan $a_{i j}=1$ berarti ada hubungan antara $\mathrm{i}$ dan $\mathrm{j}$. Hubungan dalam jejaring tak berarah bersifat simetris, artinya jika I berhubungan dengan $\mathrm{j}$, maka $\mathrm{j}$ juga berhubungan dengan i. Sifat ini berakibat nilai $a_{i j}=a_{j i}$, sehingga matriks untuk jejaring tak berarah selalu berupa matriks simetris.

$$
\boldsymbol{A} \equiv\left[\begin{array}{lllll}
a_{A A} & a_{A B} & a_{A C} & a_{A D} & a_{A E} \\
a_{B A} & a_{B B} & a_{B C} & a_{B D} & a_{B E} \\
a_{C A} & a_{C B} & a_{C C} & a_{C D} & a_{C E} \\
a_{D A} & a_{D B} & a_{D C} & a_{D D} & a_{D E} \\
a_{E A} & a_{E B} & a_{E C} & a_{E D} & a_{E E}
\end{array}\right] \equiv\left[\begin{array}{lllll}
0 & 1 & 0 & 0 & 1 \\
1 & 0 & 1 & 0 & 1 \\
0 & 1 & 0 & 1 & 0 \\
0 & 0 & 1 & 0 & 1 \\
1 & 1 & 0 & 1 & 0
\end{array}\right]
$$

Sementara itu, jejaring berarah terdiri dari hubungan-hubungan yang berarah. Dalam notasi matriks, suatu jejaring berarah A dapat digambarkan sebagai matriks B. Baris-baris dalam matriks B menunjukkan sumber hubungan, sedangkan kolom-kolom dalam matriks A menunjukkan tujuan dalam suatu hubungan berarah (Knoke \& Kuklinski, 1982). Matriks untuk jejaring berarah $\mathrm{B}$ hanya terdiri dari angka 0 dan 1 , di mana $b_{i j}=0$ berarti tidak ada hubungan dari i ke j, dan $b_{i j}=1$ berarti ada hubungan dari i ke j. Tidak seperti matriks A, matriks B tidak bersifat simetris karena sifat hubungannya tidak dapat ditukarkan. 


$$
\boldsymbol{B} \equiv\left[\begin{array}{lllll}
b_{A A} & b_{A B} & b_{A C} & b_{A D} & b_{A E} \\
b_{B A} & b_{B B} & b_{B C} & b_{B D} & b_{B E} \\
b_{C A} & b_{C B} & b_{C C} & b_{C D} & b_{C E} \\
b_{D A} & b_{D B} & b_{D C} & b_{D D} & b_{D E} \\
b_{E A} & b_{E B} & b_{E C} & b_{E D} & b_{E E}
\end{array}\right] \equiv\left[\begin{array}{lllll}
0 & 1 & 0 & 0 & 0 \\
0 & 0 & 0 & 0 & 1 \\
0 & 1 & 0 & 1 & 0 \\
0 & 0 & 0 & 0 & 0 \\
1 & 0 & 0 & 0 & 0
\end{array}\right]
$$

Analisis jejaring sosial dilakukan dengan menyusun peta yang terdiri atas titik yang menggambarkan aktor dan garis yang menggambarkan interaksi aktor. Definisi jejaring yang biasa digunakan dalam jejaring sosial berasal dari teori graf, bahwa sekumpulan titik mewakili aktor sosial atau objek dan sekumpulan garis mewakili satu (atau beberapa) hubungan sosial di antara mereka.

Hubungan-hubungan yang terjadi dalam analisis jejaring sosial juga dapat digambarkan berdasarkan informasi yang ada sebagai jejaring biner atau jejaring berbobot seperti Gambar 2. Jejaring biner merupakan hubungan yang hanya terdapat informasi tentang ada atau tidaknya suatu hubungan. Sementara itu, dalam jejaring berbobot terdapat informasi bobot yang menunjukkan kekuatan hubungan tersebut. Menurut Newman (2004), sebagian besar hubungan dalam dunia nyata memiliki bobot. Dengan kata lain, dalam dunia nyata terdapat hubungan yang lebih kuat atau lebih lemah antara dua individu.

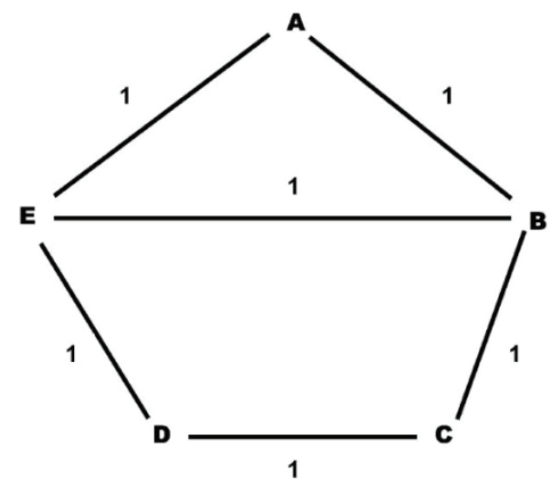

(a)

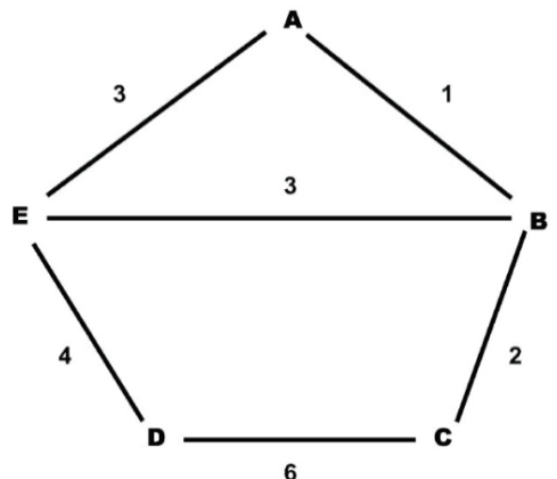

(b)

Gambar 2. Jejaring biner (a) dan jejaring berbobot (b)

Seperti halnya jejaring tak berarah dan jejaring berarah, dalam hal ini jejaring biner dan jejaring berbobot juga dapat digambarkan secara matematis menggunakan matriks. Pada jejaring biner, semua elemen matriks bernilai 0 atau 1 . Sedangkan pada jejaring berbobot, elemennya memiliki nilai non negatif yang menggambarkan bobot hubungan antar aktor.

Jejaring biner terdiri dari hubungan-hubungan biner. Dalam notasi matriks, suatu jejaring dikotomi $\mathrm{C}$ dapat digambarkan sebagai matriks $\mathrm{C}$. Matriks $\mathrm{C}$ hanya terdiri dari angka 0 dan 1 , di mana $c_{i j}=\mathbf{0}$ berarti tidak ada hubungan dari $\mathrm{i}$ ke $\mathrm{j}$, dan $c_{i j}=1$ berarti ada hubungan dari i ke j.

$$
C=\left[\begin{array}{lllll}
c_{A A} & c_{A B} & c_{A C} & c_{A D} & c_{A E} \\
c_{B A} & c_{B B} & c_{B C} & c_{B D} & c_{B E} \\
c_{C A} & c_{C B} & c_{C C} & c_{C D} & c_{C E} \\
c_{D A} & c_{D B} & c_{D C} & c_{D D} & c_{D E} \\
c_{E A} & c_{E B} & c_{E C} & c_{E D} & c_{E E}
\end{array}\right] \equiv\left[\begin{array}{lllll}
0 & 1 & 0 & 0 & 1 \\
1 & 0 & 1 & 0 & 1 \\
0 & 1 & 0 & 1 & 0 \\
0 & 0 & 1 & 0 & 1 \\
1 & 1 & 0 & 1 & 0
\end{array}\right]
$$


Sedangkan jejaring berbobot terdiri dari hubungan-hubungan berbobot. Dalam notasi matriks, suatu jejaring berbobot D dapat digambarkan sebagai matriks D. Matriks D terdiri bilangan non negatif yang menggambarkan bobot. Dengan kata lain, $d_{i j}=$ bobot hubungan i dan $\mathrm{j}$.

$$
\boldsymbol{D} \equiv\left[\begin{array}{lllll}
d_{A A} & d_{A B} & d_{A C} & d_{A D} & d_{A E} \\
d_{B A} & d_{B B} & d_{E C} & d_{B D} & d_{B E} \\
d_{C A} & d_{C B} & d_{C C} & d_{C D} & d_{C E} \\
d_{D A} & d_{D B} & d_{D C} & d_{D D} & d_{D E} \\
d_{E A} & d_{E B} & d_{E C} & d_{E D} & d_{E E}
\end{array}\right] \equiv\left[\begin{array}{lllll}
0 & 1 & 0 & 0 & 3 \\
1 & 0 & 2 & 0 & 3 \\
0 & 2 & 0 & 6 & 0 \\
0 & 0 & 6 & 0 & 4 \\
-3 & 3 & 0 & 4 & 0
\end{array}\right]
$$

Analisis jejaring sosial telah digunakan dalam pengembangan dan evaluasi kebijakan, yaitu untuk melihat jejaring kolaborasi, jejaring komunikasi, dan jejaring teknologi (Van Den Brink \& Han, 2015). Dalam konteks kebijakan penelitian, analisis jejaring sosial dapat menangkap aspek dampak dan manfaat ilmiah yang tidak diakomodir oleh ukuran lainnya (Bollen, Van de Sompel, Hagberg, \& Chute, 2009).

Konsep analisis jejaring sosial dalam publiksi ilmiah digunakan untuk mengukur hubungan antara artikel ilmiah, dilihat dari penulis, institusi, dan kata kunci di dalamnya. Hubungan antar penulis (atau institusi) sering disebut sebagai hubungan co-authorship. Sedangkan hubungan antar kata kunci sering disebut sebagai co-word. Kedua jenis hubungan tersebut menggunakan prinsip co-occurence yang menganalisis frekuensi kemunculan bersama dari pasangan penulis, institusi, maupun kata kunci. Todorov (1990) melakukan analisis coheading terhadap data publikasi ilmiah. Analisis ini menggunakan prinsip co-occurrence yang diterapkan pada kategori bidang ilmu. Kategori bidang ilmu biasanya sudah ditentukan oleh penyedia basis data publikasi ilmiah. Penerapan analisis jejaring sosial tersebut menghasilkan gambaran yang berupa peta jejaring co-authorship, peta jejaring kata kunci, dan peta jejaring bidang ilmu.

Menurut Noyons (2001), peta bidang ilmu merupakan gambaran bidang ilmu dalam dua atau tiga dimensi. Peta ini dapat dikatakan sebagai "landscape of science", simbol dalam peta tersebut menunjukkan tema dan topik pada bidang ilmu yang dipetakan. Sebagian besar peta bidang ilmu dibangun berdasarkan konsep kemunculan bersama. Semakin banyak pasangan elemen yang muncul secara bersamaan, semakin dekat hubungan keduanya. Pada peta ilmu pengetahuan, semakin dekat hubungan kedua elemen maka secara visual semakin dekat posisi kedua elemen tersebut dalam peta. Noyons (2001) juga menyebutkan bahwa peta bidang ilmu dapat disusun berdasarkan data publikasi ilmiah dengan mengasumsikan bahwa publikasi ilmiah merupakan salah satu bentuk aktivitas ilmiah. Dalam data publikasi ilmiah, terdapat banyak elemen yang dapat digunakan untuk membangun peta ilmu pengetahuan, misalnya: penulis artikel, sumber artikel, kata kunci, kode klasifikasi, dan istilah terindeks. Kata kunci biasanya diberikan oleh penulis atau penerbit jurnal ilmiah. Kode klasifikasi dan indexed terms diberikan oleh pengelola basis data publikasi. Kode klasifikasi dalam hal ini dapat berupa bidang ilmu. Setiap elemen pada peta menunjukkan struktur tertentu. Sebagai contoh, peta yang disusun berdasarkan elemen penulis artikel bertujuan untuk memperlihatkan struktur sosial dari suatu bidang penelitian. Sedangkan peta yang disusun berdasarkan kode klasifikasi dapat menunjukkan struktur hubungan antar kode tersebut. 
Berdasarkan peta bidang ilmu yang dihasilkan dapat dilihat aspek interdisipliner dari suatu kumpulan data publikasi ilmiah. Menurut Schummer (2004), terdapat beberapa pendekatan pengukuran interdisipliner, baik berdasarkan sistem kategori bidang ilmu, maupun berdasarkan konsep interdisipliner itu sendiri. Sebagian besar pendekatan yang ada menggunakan artikel ilmiah (atau paten) sebagai objek kajian. Pengukuran aspek interdisipliner pada umumnya mempertimbangkan aspek co-occurrence dari suatu elemen. Elemen yang dapat digunakan untuk mengukur aspek interdisipliner adalah elemen yang dianggap spesifik terhadap suatu bidang ilmu, misalnya: kata kunci, klasifikasi, afiliasi penulis, atau sitasi. Konsep yang mendasari anggapan tersebut adalah semakin sering dua elemen dari bidang ilmu muncul secara bersamaan, semakin kuat hubungan pertukaran antara dua bidang ilmu. Sebagai contoh, jika terdapat artikel ilmiah dengan kata kunci spesifik bidang kimia dan kata kunci spesifik bidang fisika, maka hal ini menunjukkan hubungan interdisipliner yang kuat antara bidang kimia dan fisika. Demikian juga dalam hal analisis co-classification, analisis tersebut menganalisis jumlah kategori bidang ilmu yang muncul secara bersamaan. Berbeda dengan kata kunci, kategori bidang ilmu ini biasanya ditentukan oleh manajer informasi yang profesional dan merujuk pada skema basis data besar yang lebih sistematis.

\section{METODE}

Data yang digunakan dalam penelitian adalah publikasi ilmiah kelautan dan perikanan yang dihasilkan oleh institusi yang berlokasi di Indonesia periode 2006 - 2015. Data bersumber dari basis data Scopus yang diakses pada tanggal 7 Oktober 2016. Cara pencarian yang dilakukan dengan memasukkan kata pencarian "marine", "maritime", "fishery", atau "fisheries" pada bagian "abstract, tittle, keyword". Proses ini menghasilkan 635 artikel ilmiah. Setelah pengumpulan data selesai dilakukan, beberapa prosedur dilakukan untuk menjamin bahwa data yang diolah menggunakan analisis jejaring sosial telah sesuai. Proses identifikasi bidang ilmu sesuai kategori Scopus dilakukan untuk setiap artikel melalui penelusuran di website Scopus.

Data yang telah dikumpulkan dianalisis menggunakan perangkat lunak VOSViewer. VOSViewer merupakan perangkat lunak yang dapat digunakan untuk melakukan analisis cooccurrence. Dalam penelitian ini, hasil keluaran dari perangkat lunak berupa peta yang menunjukkan keterkaitan antar-bidang ilmu. Sementara itu, untuk mengidentifikasi perubahan struktur bidang ilmu, data dikelompokkan berdasarkan tahun terbitnya menjadi dua periode, yaitu periode $1(2006-2010)$ dan periode $2(2011-2015)$.

Selanjutnya, dilakukan perbandingan terhadap peta yang terbentuk dari kedua periode tersebut dengan melihat jumlah bidang dan jejaring yang terbentuk. Jejaring yang terbentuk akan memiliki karakteristik yang terlihat secara visual dalam hal kepadatannya. Suatu jejaring yang terbentuk dikatakan padat jika jumlah elemen yang terhubung di dalamnya mendekati jumlah maksimal hubungan yang mungkin terjadi (Guandong, Zhang, \& Li, 2010). Secara matematis, density dari suatu jejaring tak berarah dirumuskan seperti persamaan (1).

$$
D=\frac{2|E|}{|\boldsymbol{V}|(|V|-1)}
$$

Di mana $|E|$ jumlah hubungan yang terbentuk, dan $|V|=$ jumlah elemen yang terdapat dalam jejaring. Density menggambarkan proporsi hubungan yang terjadi terhadap hubungan yang mungkin terjadi dalam suatu jejaring. Density memiliki nilai antara 0 dan 1 (Coleman \& More, 1983). Semakin besar nilai density suatu jejaring, semakin besar hubungan yang terjadi. 
Jejaring yang memiliki nilai density 1 menunjukkan bahwa jejaring tersebut terhubung dengan sempurna. Artinya, setiap elemen terhubung dengan semua elemen lain dalam jejaring tersebut.

\section{HASIL DAN PEMBAHASAN}

Sebaran data berdasarkan tahun diperlihatkan pada Gambar 3. Berdasarkan Gambar 3 bahwa publikasi imiah perikanan dan kelautan selama sepuluh tahun terakhir cenderung mengalami peningkatan kecuali pada tahun 2010 mengalami penurunan dari 45 artikel menjadi 31 artikel.

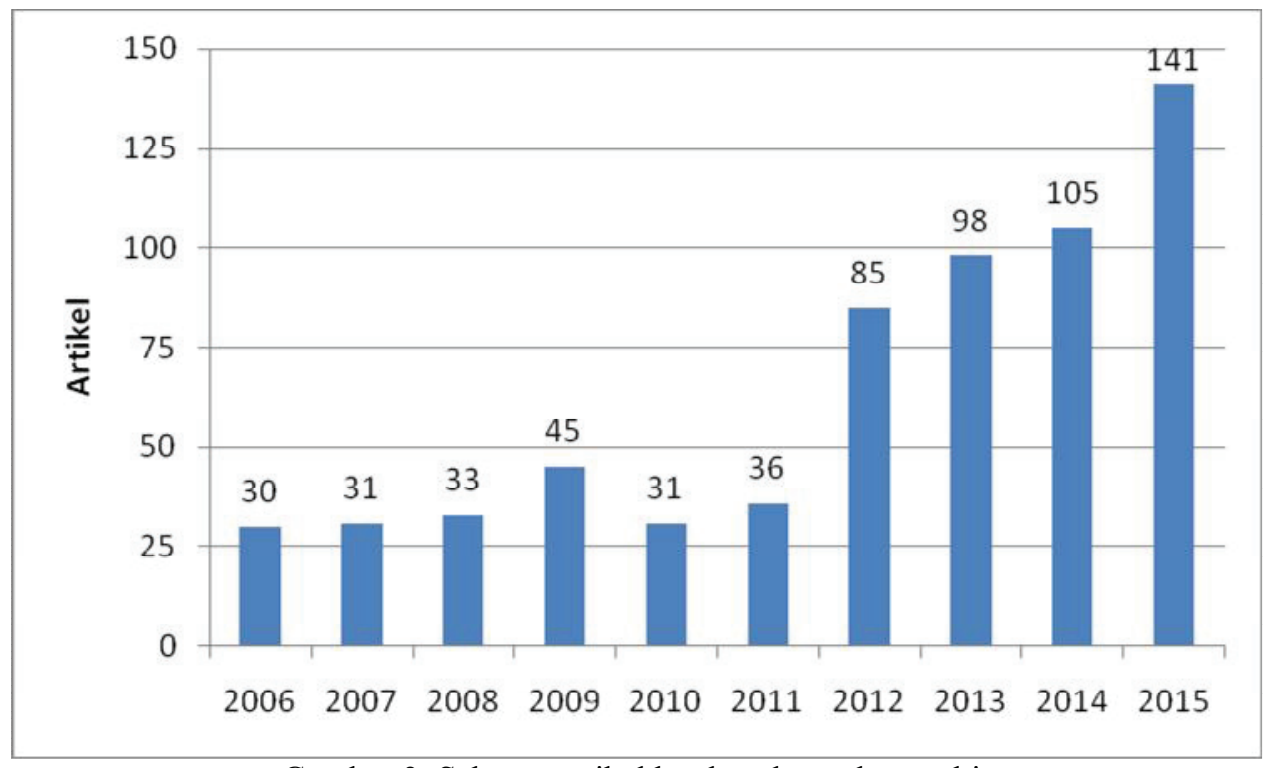

Gambar 3. Sebaran artikel berdasarkan tahun terbit

Sebaran artikel berdasarkan bidang ilmunya dapat dilihat pada Gambar 4. Berdasarkan Gambar 4, pola sebaran artikel ilmiah berdasarkan bidang ilmu pada kedua periode cenderung mirip. Artikel yang diperoleh paling banyak berasal dari bidang ilmu Agricultural and Biological Sciences, diikuti bidang ilmu Environmental Science, dan Earth and Planetary Science. Namun, pada Gambar 4 belum dapat terlihat perubahan struktur bidang ilmu pada kedua periode karena grafik yang dihasilkan masih cenderung mirip. 


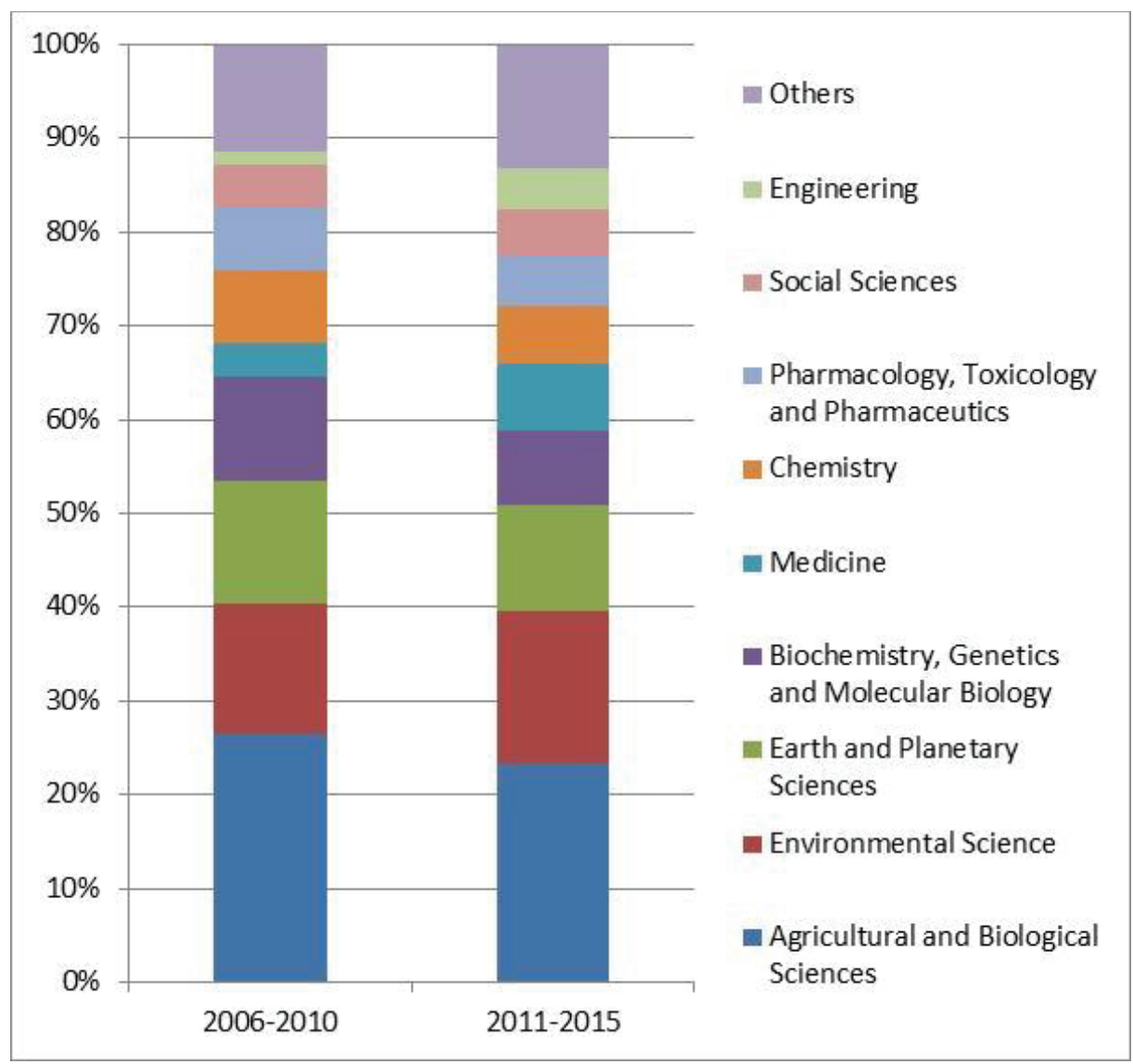

Gambar 4. Sebaran artikel selama dua periode berdasarkan bidang ilmu

Untuk mengetahui struktur perubahan bidang ilmu penelitian kelautan dan perikanan, disusun peta bidang ilmu dari penelitian tersebut. Penyusunan peta bidang ilmu menggunakan VOSViewer. VOSViewer merupakan suatu perangkat lunak untuk membantu melakukan analisis co-occurence yang digunakan dalam penelitian ini.

\subsection{Jejaring Bidang Ilmu Periode 1}

Jejaring bidang ilmu pada periode 1 terdiri dari 21 bidang ilmu yang sebagian besar membentuk jejaring, sedangkan sebagian kecil tidak terhubung dengan jejaring (Gambar 5). Jejaring yang terbentuk terdiri dari sebagian besar bidang ilmu yang saling terkait, antara lain: Agricultural and biological sciences, Environmental sciences, Biochemistryand molecular biology, Medicine, Social sciences, dan Arts and humanities. Keterkaitan bidang-bidang ilmu tersebut berarti terdapat artikel ilmiah penelitian kelautan dan perikanan yang dihasilkan oleh perpaduan dari dua atau lebih bidang ilmu dalam jejaring tersebut. Sementara itu, terdapat bidang ilmu yang belum terhubung dengan jejaring yang terbentuk. Bidang ilmu tersebut yaitu: Business, management and accounting, Mathematics, Nursing, dan Multidisciplinary. Tidak adanya hubungan keempat bidang ilmu tersebut dengan jejaring bidang ilmu yang terbentuk menunjukkan bahwa artikel ilmiah penelitian perikanan dan kelautan yang dihasilkan oleh empat bidang ilmu tersebut tidak memiliki keterkaitan dengan bidang ilmu lain. 


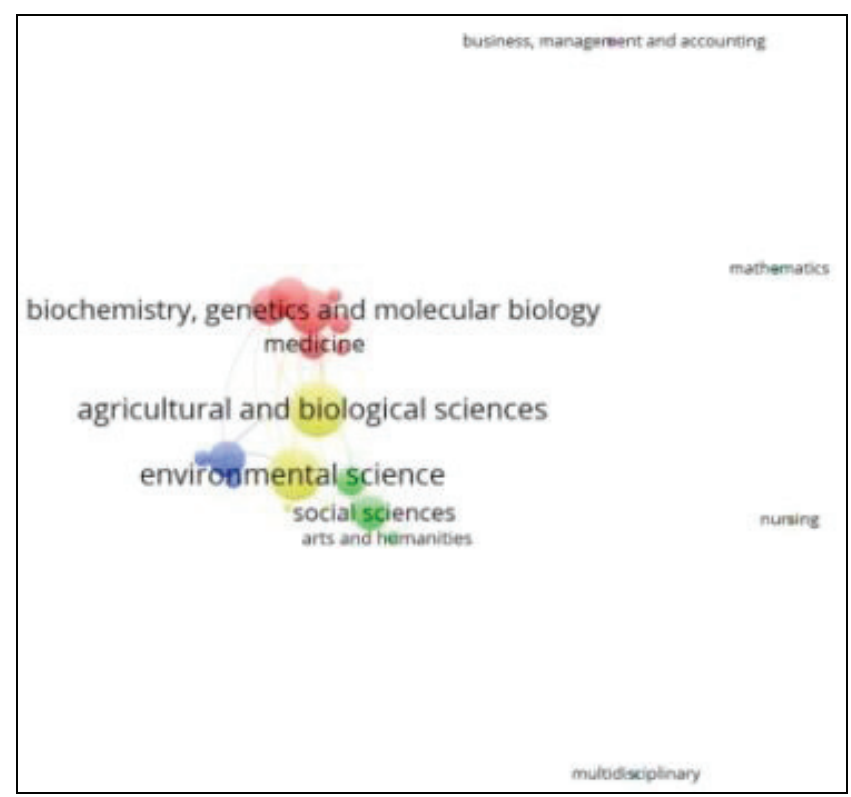

Gambar 5. Jejaring bidang ilmu periode 1

Sementara itu, jika dilihat dari warnanya, bidang-bidang ilmu yang terdapat dalam peta jejaring bidang ilmu periode 1 membentuk 8 klaster. Klaster 1 terdiri dari bidang ilmu biochemistry, genetics and molecular biology, chemistry, medicine, immunology and microbiology, chemical engineering, decision sciences, serta pharmacology, toxicology and pharmaceutics. Klaster 2 terdiri dari bidang social sciences, economics, econometrics and finance, arts and humanities, serta veterinary. Klaster 3 terdiri dari bidang earth and planetary sciences, engineering, dan energy. Klaster 4 terdiri dari bidang agricultural and biological sciences, environmental science, dan computer science. Sedangkan keempat klaster lainnya masing-masing hanya terdiri dari satu bidang ilmu saja yaitu business, management and accounting, mathematics, nursing, dan multidisciplinary.

\subsection{Jejaring Bidang Ilmu Periode 2}

Jejaring bidang ilmu pada periode 2 terdiri dari 23 bidang ilmu (Gambar 6). Pada periode 2, seluruh bidang ilmu sudah terhubung dalam jejaring. Dengan kata lain, tidak terdapat bidang ilmu yang terpisah dari bidang ilmu lainnya. Setiap bidang ilmu sudah terhubung dengan bidang ilmu lain. Jadi setiap artikel ilmiah penelitian perikanan dan kelautan pada periode ini sudah mencakup lebih dari satu bidang. 


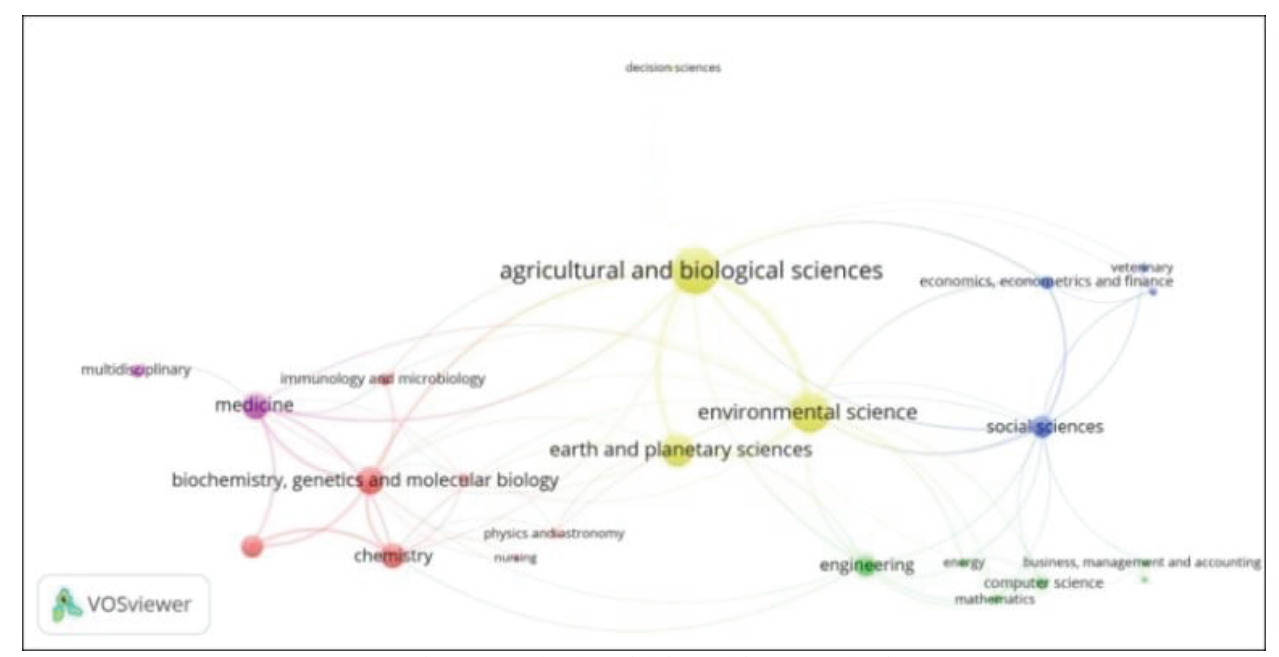

Gambar 6. Jejaring bidang ilmu periode 2

Seperti pada periode 1 jika dilihat dari warnanya, bidang-bidang ilmu yang terdapat dalam peta jejaring periode 2 membentuk 5 klaster. Klaster 1 terdiri dari bidang ilmu biochemistry, genetics and molecular biology, chemistry, immunology and microbiology, chemical engineering, pharmacology, toxicology and pharmaceutics, physics and astronomy, dan nursing. Klaster 2 terdiri dari bidang ilmu engineering, energy, computer science, business, management and accounting, mathematics, dan materials science. Klaster 3 terdiri dari bidang ilmu social sciences, economics, econometrics and finance,arts and humanities, dan veterinary. Klaster 4 terdiri dari bidang ilmu earth and planetary sciences, agricultural and biological sciences, environmental science, dan decision sciences. Sedangkan klaster 5 terdiri dari dua bidang ilmu yaitu medicine dan multidisciplinary.

\subsection{Perbandingan Jejaring Bidang Ilmu Periode 1 dan Periode 2}

Peta bidang ilmu pada publikasi ilmiah penelitian kelautan dan perikanan pada periode 1 dan periode 2 diperlihatkan pada gambar 4 . Perbandingan peta bidang ilmu pada kedua periode dilihat dari jumlah bidang ilmu, hubungan yang terbentuk, dan jumlah klaster yang terbentuk (Tabel 1). Jika dilihat dari jumlah bidang ilmunya, pada periode 1 terdapat 21 bidang ilmu sedangkan pada periode 2 terdapat 22 bidang ilmu. Bidang ilmu pada periode 1 yang tidak muncul pada periode 2 adalah bidang ilmu decision science. Sedangkan bidang ilmu pada periode 2 yang tidak muncul pada periode 1 adalah bidang ilmu physics and astronomy, dan materials science. Jika dibandingkan dengan periode 2, jejaring bidang ilmu yang terbentuk mengalami perubahan (Gambar 7). Hal ini sejalan dengan pertambahan jumlah hubungan antar bidang ilmu yang terbentuk pada periode 2 . Pada periode 1 hanya terdapat 38 hubungan yang terjadi pada 21 bidang ilmu. Periode 2 terdapat 78 hubungan yang terjadi pada 22 bidang ilmu. Perubahan yang terjadi pada periode 2 menunjukkan adanya hubungan baru pada beberapa bidang ilmu yang terjadi pada artikel ilmiah penelitian kelautan dan perikanan. Bidang ilmu business, management and accounting sudah terhubung dengan bidang ilmu Social sciences. Begitu pula dengan bidang ilmu nursing sudah terhubung dengan bidang ilmu biochemistry, genetics and molecular biology, dan bidang ilmu chemistry. Hubungan yang terjadi menunjukkan adanya hubungan pertukaran antara dua bidang ilmu untuk menghasilkan artikel ilmiah 
penelitian kelautan dan perikanan. Dengan demikian, publikasi ilmiah penelitian kelautan dan perikanan dapat dikatakan menjadi semakin interdisipliner pada periode 2 .
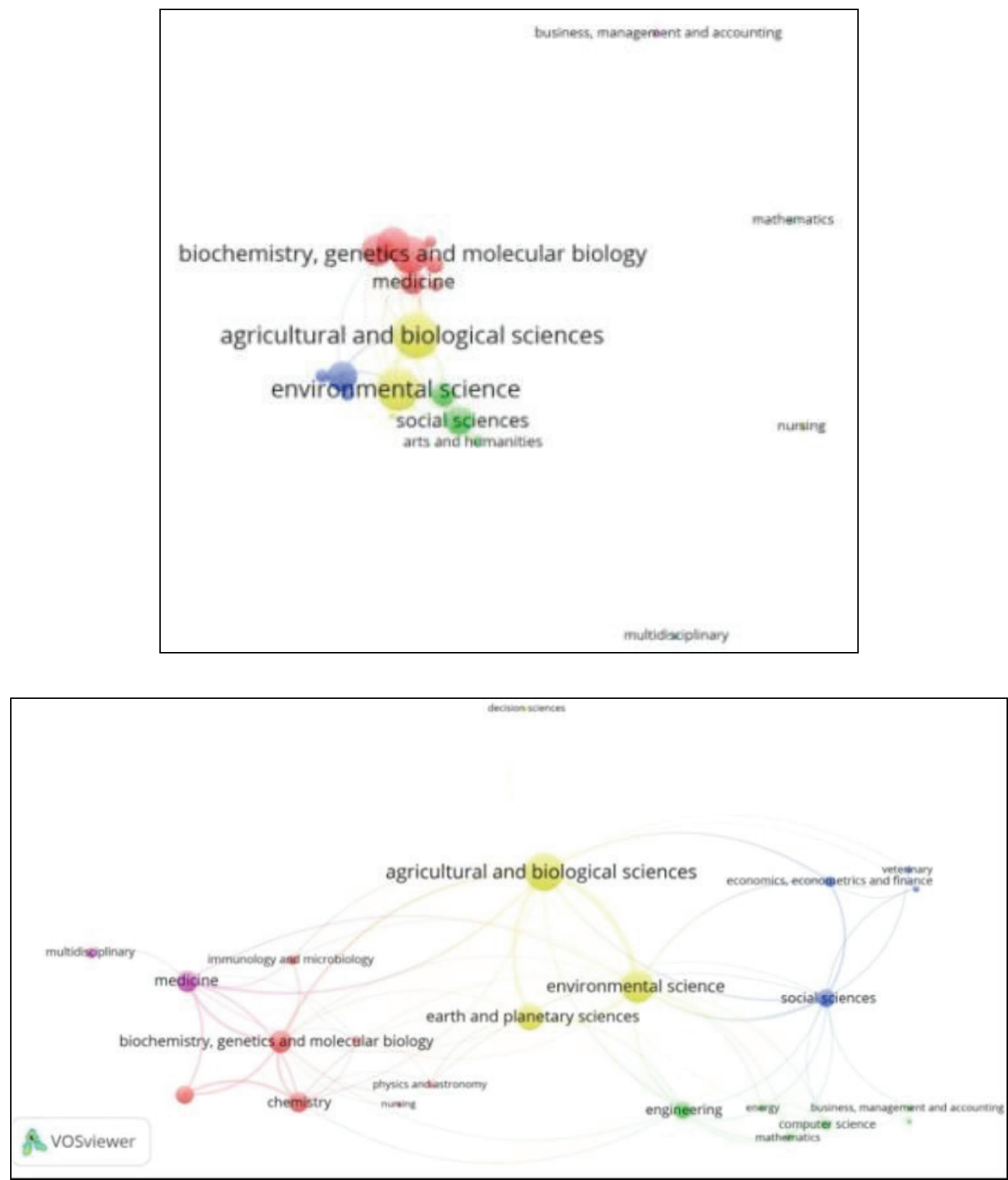

Gambar 7. Jejaring bidang ilmu pada periode 1 (kiri) dan periode 2 (kanan)

Apabila dilihat dari ukuran density yang dihasilkan, terdapat perbedaan antara jejaring bidang ilmu periode 1 dan jejaring bidang ilmu periode 2 (Tabel 1). Ukuran density jejaring bidang ilmu pada periode 1 sebesar 0,17 sedangkan pada periode 2 sebesar 0,34 . Jadi density jejaring bidang ilmu pada periode 2 dua kali lipat dengan periode 1 . Hal ini mengindikasikan bahwa jejaring bidang ilmu periode 2 cenderung lebih padat jika dibandingkan dengan periode 1. Artinya semakin banyak bidang ilmu yang terhubung dalam artikel ilmiah. Dengan kata lain, artikel ilmiah penelitian kelautan dan perikanan pada periode 2 memiliki rata-rata cakupan bidang ilmu yang lebih luas jika dibandingkan artikel ilmiah serupa pada periode 1 . 
Tabel 1. Perbandingan Jejaring Bidang Ilmu Pada Periode 1 Dan Periode 2

\begin{tabular}{|l|c|c|}
\hline & Periode 1 & Periode 2 \\
\hline Jumlah bidang ilmu & 21 & 22 \\
\hline $\begin{array}{l}\text { Bidang ilmu yang tidak ada } \\
\text { di periode lainnya }\end{array}$ & Decision sciences & $\begin{array}{c}\text { Physics and astronomy } \\
\text { Materials science }\end{array}$ \\
\hline $\begin{array}{l}\text { Jumlah hubungan yang } \\
\text { terbentuk }\end{array}$ & 38 & 78 \\
\hline Density jejaring & 0,17 & 0,34 \\
\hline Klaster yang terbentuk & 8 & 5 \\
\hline Total links strength & 156 & 662 \\
\hline Rata-rata DC & 4,11 & 8,49 \\
\hline
\end{tabular}

\section{KESIMPULAN}

Berdasarkan hasil penelitian ini, dapat disimpulkan bahwa analisis jejaring sosial dapat diterapkan untuk memetakan bidang ilmu pada data publikasi ilmiah. Pemetaan tersebut juga dapat melihat perubahan struktur keterkaitan bidang ilmu dari suatu kumpulan publikasi dengan batasan tertentu. Secara khusus, penelitian ini menunjukkan bahwa jejaring bidang ilmu penelitian perikanan dan kelautan mengalami perubahan selama tahun 2006-2015. Perubahan tersebut dapat dilihat dari jumlah dan jenis bidang ilmu yang muncul serta pada keterkaitan antar bidang ilmu pada periode 2 (2011-2015) yang lebih banyak terjadi jika dibandingkan dengan keterkaitan antar bidang ilmu pada periode 1 (2006-2010). Jika dilihat dari ukuran density-nya, jejaring bidang ilmu pada periode 2 dua kali lebih padat dibandingkan jejaring bidang ilmu pada periode 1. Dengan demikian dapat dikatakan bahwa penelitian perikanan dan kelautan Indonesia menjadi semakin multidisiplin pada periode 2.

\section{DAFTAR PUSTAKA}

Bollen, J., H. Van de Sompel, A. Hagberg, dan R. Chute. 2009. A Principal Component Analysis of 39 Scientific Impact Measures. PLOS One, 1-11.

Bruno, U. 2006. Evolution of Marine Resources Management: A Scientometric Analysis, 1-12. Proceedings of the International Institute of Fisheries Economics \& Tarde (IIFET), July, page 11-14. Portsmouth: UK.

Coleman, T., dan J. More. 1983. Estimation of Sparse Jacobian Matrices and Graph Coloring. SIAM Journal on Numerical Analysis, 187-209.

Dias, J. D., N. R. Simoes, dan C. C. Bonecker. 2012. Net Cages Infish Farming: a Scientometric Analysis. Acta Limonologia Brasiliensia, 12-17.

Food and Agriculture Organization. 2015. FAO Statistical Pocketbook, World Food and Agriculture 2015. Rome: Food and Agriculture Organization of the United Nations.

Guandong, X., Y. Zhang, dan L. Li. 2010. Web Mining and Social Networking: Techniques and Applications. Springer.

Hardiana, I., dan B. Trixie. 2014. "Potensi Indonesia sebagai Negara Maritim". Metro TV News, October 22. (http://ekonomi.metrotvnews.com/read/2014/10/22/308561/potensi-indonesiasebagai-negara-maritim, diakses 15 November 2016). 
Katerndahl, D. 2012. Evolution of the Research Collaboration Network in a Productive Department. Journal of Evaluation in Clinical Practice, Vol.18, 195-201.

Kementerian Sekretariat Negara Republik Indonesia. 2015. "Indonesia sebagai Poros Maritim Dunia". 13 November. (http://presidenri.go.id/maritim/indonesia-sebagai-poros-maritimdunia.html, diakses 14 November 2016).

Knoke, D., dan J. Kuklinski. 1982. Network Analysis. Beverly Hills, C. A.: Sage Publications.

Kumaresan, R., K. Vinitha, dan K. Kannan. 2015. Scientometric Analysis of Seaweed Research with Reference to Web of Science. Library Philosophy and Practice.

Lasabuda, R. 2013. Pembangunan Wilayah Pesisir dan Lautan dalam Perspektif Negara Kepulauan Republik Indonesia. Jurnal Ilmiah Platax, 92-101.

Maryati, I., A. Yoganingrum, dan A. Sihombing. 2016. Science Mapping as a Tool for Presentation of Information on The Information Repackaging for The Policy Maker. Makalah Konferensi Internasional 2016 Peran Science Mapping dalam Pengembangan Ilmu Pengetahuan di Indonesia. Yogyakarta: Universitas Gadjah Mada.

Monclar, R. 2011. "Using Social Network Analysis for Collaboration and Team Formation Identification" diedit oleh Weiming Shen, Jean-Paul Barthès, Junzhou Luo, Peter Kropf, Michel Pouly, Jianming Yong, Yunjiao Xue, and Milton Ramos, 562-569. Proceedings of the 2011 15th International Conference on Computer Supported Cooperative Work in Design (CSCWD); June 8 - 10. Switzerland - Lausanne.

Nadhiroh, I. 2015. Analisis Jaringan Co-Authorship Publikasi Ilmiah Internasional Indonesia dalam Penguatan Iptek Masa Depan (Bidang Energi, Pangan, dan Kelautan). Jakarta: Pappiptek LIPI.

Newman, M. 2004. Complex Networks. Springer Berlin Heidelberg.

Newman, M., A. Barabasi, dan D. Watts. 2006. The Structure and Dynamics of Networks. Princeton University Press.

Spasser, M. 1997. Mapping the Terrain of Pharmacy: Co-classification Analysis of the International Pharmaceutical Abstracts Database. Scientometrics, 77-97.

Streeter, C., dan D. Gillespie. 1992. Social Network Analysis. Journal of Social Service Research, 201-222.

Todorov, R. 1990. Representing Canadian geophysiscs: A Bibliometric Approach. Proceeding on the 2nd International Conference on Bibliometrics, Scientometrics, and Informetrics. London: Elsevier Science Pubblishers B.V., page 291-307.

Van Den Brink, C., dan S. Han. 2015. Application of Social Network Analysis for Analyzing the Relationships Between Root and Direct Causes of Defects. Modern Applied Science, 1220 .

Wasserman, S., dan K.Faust. 1994. Social Network Analysis: Methods and Applications. Cambridge: Cambridge University. 